\title{
Sex-Specific Parameters of Ascending Aorta, Descending Aorta and Pulmonary Trunk by Computed Tomographic Angiography with Impact of Age, Hypertension, Smoking and Diabetes
}

\author{
Parámetros Específicos de la Parte Ascendente de la Aorta, Parte Descendente de la Aorta y \\ Tronco Pulmonar Analizados Mediante Angiografía por Tomografía Computadorizada Relacionados \\ con el Sexo, Impacto de la Edad, Hipertensión, Tabaquismo y Diabetes
}

\author{
Amjad S. Shatarat*; Maher T. AL-Hadidi*; Darwish H. Badran*; Faraj F. Bustami*; Azmy M. AL-Hadidy**; \\ Emad S. Tarawneh"*; Nathir M. Obeidat ${ }^{* * *}$ \& Sherin W. Abd El Malek ${ }^{* * * * *}$
}

\begin{abstract}
SHATARAT, A. S.; AL-HADIDI, M. T.; BADRAN, D. H.; BUSTAMI, F. F.; AL-HADIDY, A. M.; TARAWNEH, E. S.; OBEIDAT, N. M. \& ABD EL MALEK, S. W. Sex-Specific parameters of ascending aorta, descending aorta and pulmonary trunk by computed tomographic angiography with impact of age, hypertension, smoking and diabetes. Int. J. Morphol., 33(4):1411-1418, 2015.

SUMMARY: This study aims at establishing whether transverse diameter (TD) and cross sectional-area (CSA) of the ascending aorta (AA), descending aorta (DA) and pulmonary trunk (PT) measured by computerized tomographic angiography (CTA) altered by sex, age, hypertension, smoking and diabetes. CTA examinations of the TD and CSA of the AA, DA and PT of 100 patients aged 49.5 \pm 16.9 years (range 16-78 years) selected between January 2009 to May 2011 from those referred to Radiology Department, Jordan University Hospital, Faculty of Medicine, University of Jordan, Amman, Jordan for advanced evaluation. Measurements were made in the axial plane at the upper border of the six thoracic vertebrae. Patients were divided into three age groups. Significance of differences in parameters between age groups was calculated. Assessment ratios were considered. It was found that parameters of the three arteries were significantly larger in men than in women $(\mathrm{P}=<0.05)$ and increased with age. Hypertension increased diameters of AA and DA in both genders $(\mathrm{P}=0.001)$ and of $\mathrm{PT}$ in men $(\mathrm{P}=0.01)$. Smoking significantly decreased parameters of $\mathrm{PT}$ in men $(\mathrm{P}=0.01)$. Diabetes increased parameters of the three arteries in both genders, significantly increased parameters of $\mathrm{PT}$ in men $(\mathrm{P}=<0.05)$ and parameters of DA in women $(\mathrm{P}=<0.05)$. It is concluded that studied parameters were larger in men and increased with age of our patients. Distinctive differences in measurements appeared in hypertensive, smokers, and diabetic patients.
\end{abstract}

KEY WORDS: Ascending aorta; Descending aorta; Pulmonary trunk; Computerized tomographic angiography.

\section{INTRODUCCIÓN}

The aorta and pulmonary trunk undergo continuous structural remodeling of their wall and volumetric capacity throughout life presumably in response to hemodynamic changes consequence to body changing requests (Hager et al., 2002; Johnson et al., 2008; Mao et al., 2008). Various diseases that cause obstruction or dilatation of the aorta such as stenosis, ectasia, hypoplasia, aneurysm, and aortomegaly could alter its structure and function (Hager et al.). Assessment and follow up of such structural changes done by radiologic angiography, transesophageal echocardiography (TEE), computerized tomography (CT), and magnetic resonance imaging (MRI). However, these modalities have their diagnostic value, CT evolved to be the mainstay of evaluation owing to its accuracy, reproducibility, simplicity, speed, and true 3-dimensional capabilities (Wolak et al., 2008). With a standard method such as CT angiography (CTA), one should not employ values obtained from other techniques.

Pulmonary hypertension (PH) can be potentially lifethreatening leading to heart failure and its early diagnosis maybe the key to its optimal treatment (Rubin, 2006). Right

\footnotetext{
Department of Anatomy and Histology, Faculty of Medicine, University of Jordan, Amman, Jordan.

** Department of Radiology and Nuclear Medicine, Faculty of Medicine, University of Jordan, Amman, Jordan.

*** Department of Internal Medicine, Faculty of Medicine, University of Jordan, Amman, Jordan.

***** Department of Anatomy, Faculty of Medicine, Ain-Shams University, Cairo, Egypt.
} 
heart catheterization is the gold standard for the measurement of pulmonary arterial pressure (Devaraj \& Hansell, 2009). However, its invasive nature exacerbates its risk. Chan et al. (2011) proved that measuring pulmonary artery diameter by CT has an excellent diagnostic value for PH. Such noninvasive approach can reduce patient's risk and allow earlier PH diagnosis. Though management decisions strongly depends on comparison of measured parameters with normal values, little has been published in reference to normal CT limits of thoracic aorta and pulmonary trunk (PT) parameters, as well as their association to variable factors (Wolak et al.; Lin et al., 2008; Nevsky et al., 2011).

Aging signs that may influence arterial dimensions are changes of vascular wall structure and elastin fragmentation (Wolak et al.). Investigations related to hypertension and large size capacitance arteries are scarce and almost limited to the aortic root (Cuspidi et al., 2011). Age, sex and blood pressure as well as cardiovascular risk factors such as smoking and diabetes could play a role on dilatation or constriction of large thoracic vessels (Webb \& Higgins, 2004).

The purposes of this study were to detect effect of sex, age, hypertension, smoking and diabetes mellitus on the transverse diameter (TD) and cross sectional-area (CSA) of the ascending aorta (AA), descending aorta (DA) and PT in the same patient by using CTA. In addition, select signifying ratios relating various parameters.

\section{MATERIAL AND METHOD}

One hundred patients (49 men and 51 women, $49.5 \pm 16.9$ years, range 16-78 years) were randomly selected between January 2009 to May 2011 from those referred to the Radiology Department, Jordan University Hospital, Amman, Jordan, for thoracic CTA for advanced evaluation of possible cardiac or pulmonary diseases. Patients referred with trauma from the emergency, or from critical care units and those proved to have aortopathy; cardiopathy or pulmonary diseases were excluded. Patients were divided into three age subgroups (Table IV). All patients provided informed consents. Our Institutional review Board approved this study.

Technique. Each patient received $100 \mathrm{ml}$ of Iopromide (Ultravist, Bayer Health Care Pharmaceuticals, Schering AG, Berlin, Germany) containing $370 \mathrm{mg}$ of Iodine /ml via median cubital vein while in supine position. The injection rate was automated at $3 \mathrm{ml} /$ second. Thirty seconds post injection, arterial phase axial images in full inspiration done below bifurcation of the trachea on the section through the upper border of the sixth thoracic vertebra. A craniocaudal scanning was achieved in 30 seconds, using a single slice CT scanner (Somatom Plus 4, Siemens, Erlangen, Germany); 5-mm thick sections, $\mathrm{KV}=120, \mathrm{~mA}=240, \mathrm{FOV}=330 \times 330 \mathrm{~mm}$.

Measurements. All images analyzed independently by two consultants on a workstation to resolve distinctions of interpretation. The scans were viewed on mediastinal windows. The CT source images reconstructed at 2-mm slices on Syngo-workstation (Siemens Medical Solutions, Erlangen, Germany) displayed on a 512 X 512 matrix. The best image showing the highest signal of the aorta and pulmonary trunk was selected.

The TD and CSA of the AA, DA and PT were measured by Syngo fastView software (Siemens Medical Solutions, Department SW, Erlangen, Germany) at the same slice images and recorded to the nearest millimeter. The widest intraluminal TD of the AA (TAA), DA (TDA) and PT (TPT) were done at the same level (Fig. 1). The intraluminal CSA of the AA (AAA), DA (ADA) and PT (APT) were measured by presuming the cross sections to be circular and labeled in $\mathrm{cm}^{2}$ (Fig. 2). The parameters of each artery were measured at the external confines of the contrast.

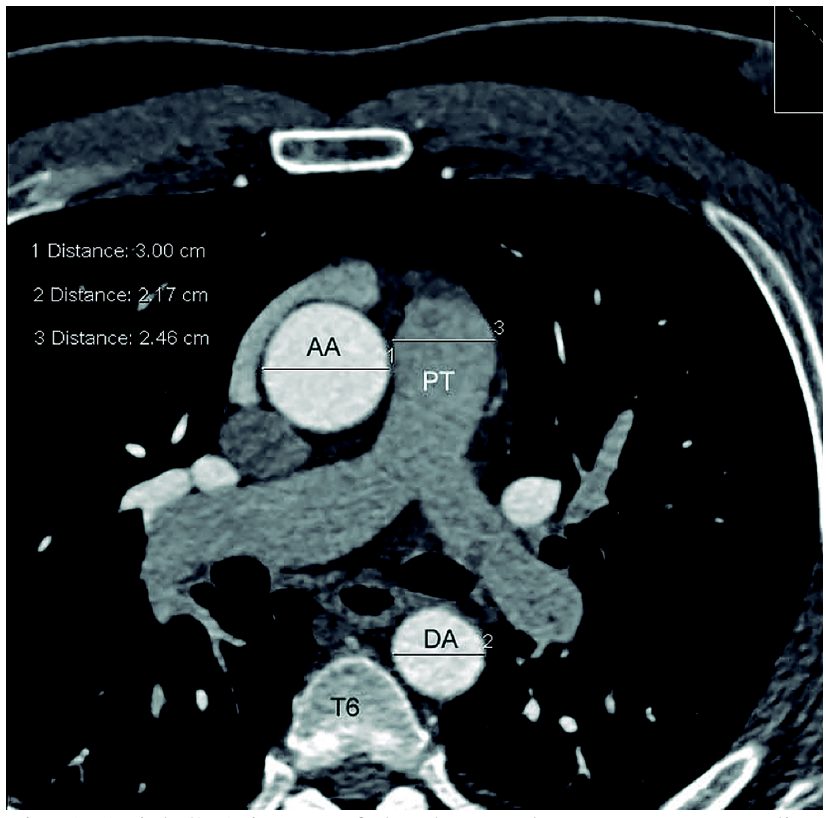

Fig. 1. Axial CTA image of the thorax, demonstrates ascending aorta, descending aorta and pulmonary trunk at the upper border of the sixth thoracic vertebra. Showing positions of markers for measuring the widest intraluminal transverse diameters. AA= ascending aorta, $\mathrm{DA}=$ descending aorta, $\mathrm{PT}=$ pulmonary trunk.

The mean \pm SD of the TDs and CSAs were calculated. Evaluator ratios were considered such as TAA/TDA, TAA/ TPT, TDA/TPT, AAA/ADA, AAA/APT and ADA/APT to detect any correlation between parameters in each sex. Paired 
SHATARAT, A. S.; AL-HADIDI, M. T.; BADRAN, D. H.; BUSTAMI, F. F.; AL-HADIDY, A. M.; TARAWNEH, E. S.; OBEIDAT, N. M. \& ABD EL MALEK, S. W. Sex-Specific parameters of ascending aorta, descending aorta and pulmonary trunk by computed tomographic angiography with impact of age, hypertension, smoking and diabetes. Int. J. Morphol., 33(4):1411-1418, 2015.

t-test used to determine significance of differences between the TD and CSA for each individual artery in each sex and significance of differences of the TD and CSA for AA, DA and PT between the three age subgroups in each sex was calculated by ANOVA (single factor test). The level of significance was accepted as $\mathrm{P} \leq 0.05$. All data were analyzed by using an IBM compatible PC.

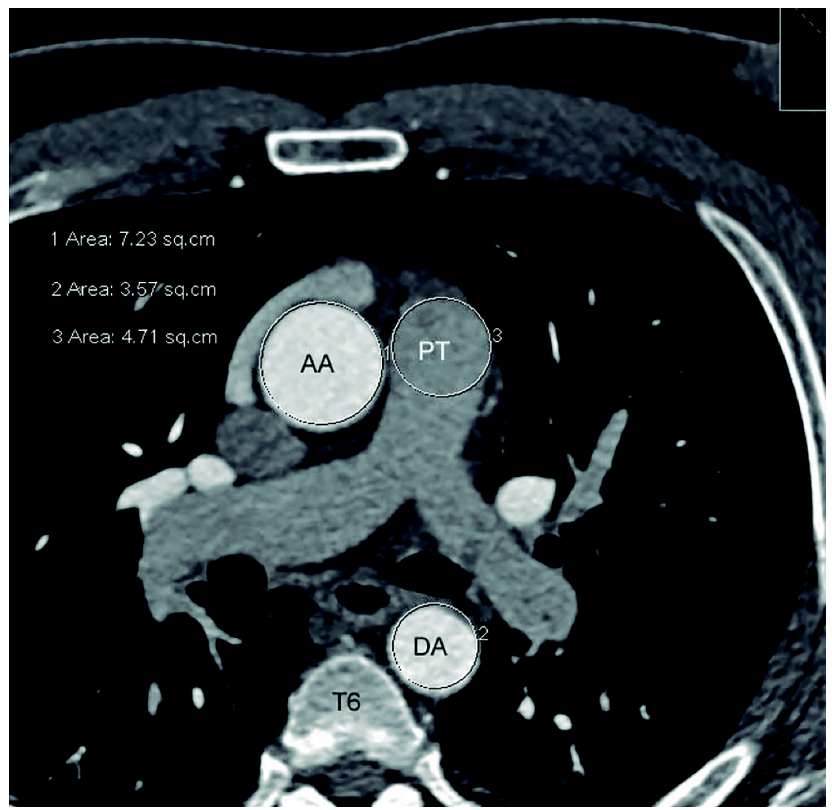

Fig. 2. Axial CTA image of the thorax, demonstrates ascending aorta, descending aorta and pulmonary trunk at the same level of Figure 1. It shows positions of markers for measuring the widest intraluminal cross sectional-area. $\mathrm{AA}=$ ascending aorta, $\mathrm{DA}=$ descending aorta, $\mathrm{PT}=$ pulmonary trunk, $\mathrm{T} 6=$ sixth thoracic vertebra.

\section{RESULTS}

The mean \pm SD of TD and CSA of the AA, DA and $\mathrm{PT}$ are reported in relation to sex, along with significant differences in (Table I). In general, the TD and CSA of AA, DA and PT were significantly larger in men than in women $(\mathrm{P}=<0.05)$ (Table I). The TAA/TDA, TAA/TPT, AAA/ADA, and AAA/APT ratios showed high significant correlation in men and women (Table II and III). The TDA/TPT ratio showed significant correlation $(\mathrm{P}=<0.001)$ in women only (Table II). Moreover, ADA/APT ratio showed significant correlation $(\mathrm{P}=<0.01)$ in women only (Table III).

The mean \pm SD of TD and CSA of the AA, DA and PT in the different age subgroups of men and women are given in (Table IV). The Table indicates that the TD and CSA of the AA, DA and PT showed a continuous increase from younger age subgroup to older ones in men and women. Another indication obtained, while TD and CSA of AA, DA and $\mathrm{PT}$ demonstrated significant age-related differences $(\mathrm{P}=$ 0.05) in both sexs, the CSA of PT in women failed. Values of AA in men subgroups were larger than in women. Values of AA were larger than DA in all subgroups of both sexs (Table IV).

When hypertension correlated as a clinical predictor to TD and CSA of the AA, DA and PT, hypertensive patients showed high significant increasing effect on the AA and DA in both sexes $(\mathrm{P}=0.001)$ and the $\mathrm{PT}$ in men $(\mathrm{P}=0.01)$ (Table IV). Effect of smoking on TD and CSA of AA, DA and PT revealed that smoking had significant decreasing effect on TD and CSA of the PT in men only $(\mathrm{P}=0.01)$ (Table IV).

Table I. Transverse diameter and cross sectional-area of ascending aorta, descending aorta and pulmonary trunk in relation to sex.

\begin{tabular}{lccccccc}
\hline \multirow{2}{*}{ S ex } & Patients & \multicolumn{3}{c}{ Transverse diameter $/ \mathbf{~ m m}$} & \multicolumn{2}{c}{ Cross section area $/ \mathbf{m m}^{2}$} \\
\cline { 3 - 8 } & $\mathbf{n = 1 0 0}$ & AA & DA & PT & AA & DA & PT \\
\hline Men & 49 & $3.37 \pm 0.56$ & $2.59 \pm 0.48$ & $2.65 \pm 0.51$ & $9.03 \pm 3.22$ & $5.44 \pm 2.02$ & $5.72 \pm 2.20$ \\
W omen & 51 & $3.02 \pm 0.40$ & $2.21 \pm 0.38$ & $2.43 \pm 0.37$ & $7.28 \pm 1.90$ & $3.98 \pm 1.33$ & $4.73 \pm 1.44$ \\
P value * & & 0.001 & $<0.001$ & 0.009 & $<0.001$ & $<0.001$ & 0.01 \\
\hline
\end{tabular}

Values are expressed as Mean $\pm \mathrm{SD} . \mathrm{n}=$ number of patients, $\mathrm{AA}=$ Ascending aorta, $\mathrm{DA}=$ Descending aorta, $\mathrm{PT}=$ Pulmonary trunk. $*=$ Student t-test

Table II. The ratio between transverse diameters of the ascending aorta, descending aorta and pulmonary trunk correlated in each sex.

\begin{tabular}{|c|c|c|c|c|c|c|}
\hline \multirow[t]{2}{*}{ Variables } & \multicolumn{2}{|c|}{$\begin{array}{c}\text { Ratio between } \\
\text { TD of AA and DA }\end{array}$} & \multicolumn{2}{|c|}{$\begin{array}{c}\text { Ratio between } \\
\text { TD of AA and PT }\end{array}$} & \multicolumn{2}{|c|}{$\begin{array}{c}\text { Ratio between } \\
\text { TD of DA and PT }\end{array}$} \\
\hline & TAA / TDA & $P$ value * & TAA / TPT & P value * & TDA / TPT & P value * \\
\hline Men & $1.32 \pm 0.17$ & $<0.001$ & $1.30 \pm 0.21$ & $<0.001$ & $1.00 \pm 0.18$ & 0.54 \\
\hline Women & $1.38 \pm 0.16$ & $<0.001$ & $1.26 \pm 0.18$ & $<0.001$ & $0.92 \pm 0.16$ & 0.01 \\
\hline
\end{tabular}

Values are expressed as Mean $\pm \mathrm{SD}$. $\mathrm{TD}=$ transverse diameter, $\mathrm{AA}=$ ascending aorta, $\mathrm{DA}=$ descending aorta, $\mathrm{PT}=$ pulmonary trunk. $\mathrm{TAA}=$ transverse diameter of ascending aorta, $\mathrm{TDA}=$ transverse diameter of descending aorta, $\mathrm{TPT}=$ transverse diameter of pulmonary trunk. * $=$ Student $\mathrm{t}$-test. 
SHATARAT, A. S.; AL-HADIDI, M. T.; BADRAN, D. H.; BUSTAMI, F. F.; AL-HADIDY, A. M.; TARAWNEH, E. S.; OBEIDAT, N. M. \& ABD EL MALEK, S. W. Sex-Specific parameters of ascending aorta, descending aorta and pulmonary trunk by computed tomographic angiography with impact of age, hypertension, smoking and diabetes. Int. J. Morphol., 33(4): 1411-1418, 2015.

Diabetic patients had larger TD and CSA of AA, DA and PT than non-diabetics in both sexs. While diabetic men showed significant increases in TD and CSA of the PT $(\mathrm{P}=<0.05)$, diabetic women showed high significant increase in TD and CSA of DA $(\mathrm{P}=<0.05)($ Table IV).

Table III. The ratio between cross sectional-area of the ascending aorta, descending aorta and pulmonary trunk correlated in each sex.

\begin{tabular}{lcccccc}
\hline \multirow{2}{*}{ Variables } & \multicolumn{2}{c}{$\begin{array}{c}\text { Ratio between } \\
\text { CSA of AA and DA }\end{array}$} & \multicolumn{2}{c}{$\begin{array}{c}\text { Correlation between } \\
\text { CSA of AA and PT }\end{array}$} & \multicolumn{2}{c}{$\begin{array}{c}\text { Correlation betwe en } \\
\text { CSA of DA and PT }\end{array}$} \\
\cline { 2 - 7 } & AAA / ADA & P value * & AAA / APT & P value * & ADA / APT & P value * \\
\hline Men & $1.74 \pm 0.49$ & $<0.001$ & $1.69 \pm 0.60$ & $<0.001$ & $1.02 \pm 0.37$ & 0.52 \\
Women & $1.92 \pm 0.43$ & $<0.001$ & $1.62 \pm 0.47$ & $<0.001$ & $0.88 \pm 0.30$ & 0.01 \\
\hline
\end{tabular}

Values are expressed as Mean $\pm \mathrm{SD}$. $\mathrm{CSA}=$ cross sectional-area, $\mathrm{AA}=$ ascending aorta, $\mathrm{DA}=$ descending aorta, $\mathrm{PT}=$ pulmonary trunk. $\mathrm{AAA}=$ cross sectional-area of ascending aorta, $\mathrm{ADA}=$ cross sectional-area of descending aorta, $\mathrm{APT}=$ cross sectional-area of pulmonary trunk. *= Student t-test.

\section{DISCUSSION}

Reference values for TDs and CSAs of the AA, DA and PT at the upper border of the sixth thoracic vertebra as confirmed by CTA are limited in adults. The present study has confirmed that the TDs and CSAs of the AA, DA and PT were larger in men than in women (Table I) and vary significantly in the three-age subgroups (Table IV). We presumed that the age- and sex-related nature of changes in the relevant parameters of aorta and PT could increase or decrease in some age groups; suggest that these are probably normal changes determined by changing functional demands on these large vessels as the individual ages.

The sex-related changes in the transverse diameters of the AA and DA in the literature are controversial (Hager et al.; Mao et al.; Wolak et al.; Aronberg et al., 1984; Kaplan et al., 2007). The findings of the present study extend the reports of Wolak et al. (2008) and Kaplan et al. (2007), by showing that TAA and TDA are significantly larger in men than in women (Table I). Hager et al., concluded that sex has weak influence on aortic diameters and men had larger values than women of $3.2 \mathrm{~mm}$ or below. This different view could be related to measuring the aorta at lower levels than ours. Moreover, cross sectional area of the AA and DA in this paper (Table I) is sex-related and in agreement with former findings (Towfiq et al., 1986).

Shearman et al. (2003) pointed out the important role of estrogen on the vulnerability of cardiovascular diseases. Estrogen was found to have inhibitory effect related to aortic elastase enzyme that ceases degradation of aortic wall elastin and collagen (Hannawa et al., 2009). Estrogen deficiency in post-menopausal women cause high frequency of aortic aneurysm, thus estrogen defined as the major factor of increasing expandability of aorta (Hannawa et al.; Sato et al., 2009). The current study has the novelty in describing the relation between parameters of PT in men and women. These results confirmed that TD and CSA of PT were significant with sex (Table I). In addition, men had larger PT values than in women (Table I), concordant with the results of Edwards et al. (1998) and Karazincir et al. (2008). Testosterone might cause vasodilation of pulmonary vessels in our men (Rowell et al., 2009).

The TAA/TDA, TAA/TPT, AAA/ADA, and AAA/ APT ratios showed high significant correlation in men and women (Table II and III). Since the TDA/TPT and ADA/ APT ratios were significant in women only (Table II and III) and its failure in men may be related to the dilatation of their PT by testosterone (Rowell et al., 2009). It is interesting to note that these ratios maintained numbers as follows: TAA/ TDA and TAA/TPT <1.4 (Table II), the AAA/ADA <2.0 and the AAA/APT $<1.7$ (Table III) in both sexes. In addition, the TDA/TPT and ADA/APT maintained a ratio 1.0 in men and $<1.0$ in women (Table II and III). The question born in mind, are these numbers reliable to predict aortic or pulmonary diseases? This could be answered by contrasting ratios of patients to healthy subjects.

Published CT evidences showed that age is one of the prime factors affecting parameters of aorta and PT of individuals during aging (Towfiq et al.; Edwards et al.; Rowell et al.). The present study indicated that TD of the AA and DA related directly to age and showed significant differences in both sexs (Table IV). The report by Hager et al., confirmed that diameters of the thoracic aorta from valve sinus to diaphragmatic level increased significantly with age, though done on CT sagittal images, still similar to our findings in that part. Furthermore, Wolak et al. concluded 
SHATARAT, A. S.; AL-HADIDI, M. T.; BADRAN, D. H.; BUSTAMI, F. F.; AL-HADIDY, A. M.; TARAWNEH, E. S.; OBEIDAT, N. M. \& ABD EL MALEK, S. W. Sex-Specific parameters of ascending aorta, descending aorta and pulmonary trunk by computed tomographic angiography with impact of age, hypertension, smoking and diabetes. Int. J. Morphol., 33(4):1411-1418, 2015.

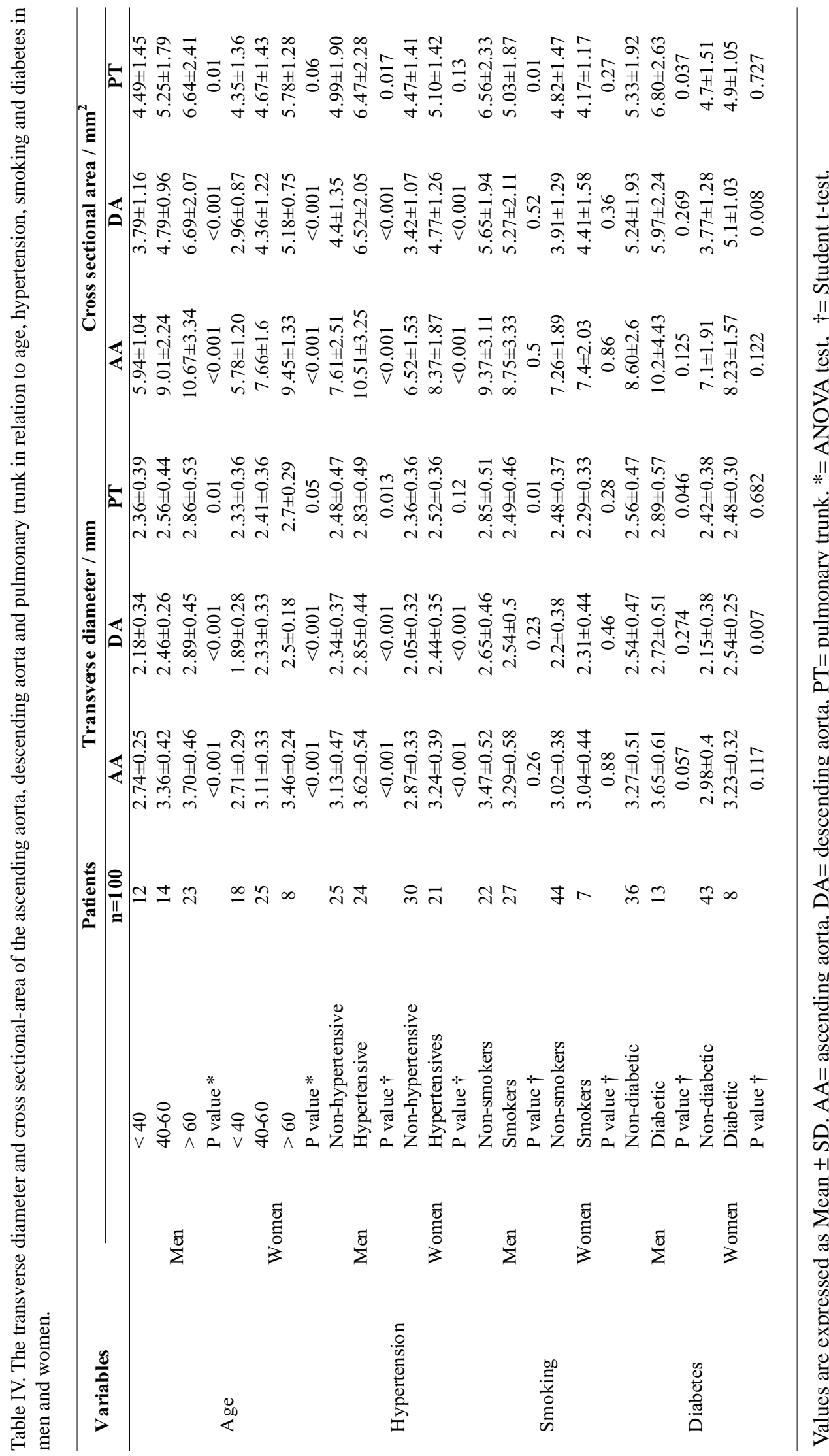

that aortic diameter relates directly to age and men sex and in itself, was a significant predictor only when interrelating with age.Older men had larger aorta than women of similar age and younger men had larger aorta than women of similar age. These results are in agreement with this study, which showed significant differences between men and women throughout life (Table IV). Lin et al., established that diameters of AA were less influenced with age than DA, whereas Aronberg et al., and the present study showed that parameters of AA were larger than DA in all age subgroups of both sexs (Table IV). The intraluminal diameter of AA was found to increase significantly with age. Although their age groups similar to ours, values were larger, since measurements done at mid right pulmonary artery level were higher than ours.

The present study showed that TD and CSA of AA, DA and PT related directly to age in both sexes (Table IV). Therefore, age-related changes could increase the parametersof the AA, DA and PT in some age groups or decrease them in others. This trend appears in agreement with the pattern of age-related changes reported on aorta and pulmonary arteries (Hager et al.; Mao et al.; Wolak et al.; Aronberg et al.; 
SHATARAT, A. S.; AL-HADIDI, M. T.; BADRAN, D. H.; BUSTAMI, F. F.; AL-HADIDY, A. M.; TARAWNEH, E. S.; OBEIDAT, N. M. \& ABD EL MALEK, S. W. Sex-Specific parameters of ascending aorta, descending aorta and pulmonary trunk by computed tomographic angiography with impact of age, hypertension, smoking and diabetes. Int. J. Morphol., 33(4): 1411-1418, 2015.

Kaplan et al.). These reports shed light on structural changes inside various components of thoracic arteries such as; their dimensions characterized by alternating phases of increase and decrease during aging. Signs of aging in the aorta are wall thickening, elastin fragmentation, cystic necrosis and fibrosis of media and adventitia, thus aortic elasticity decreased followed by widening or narrowing (Hager et al.; Mao et al.; Schlatmann \& Becker, 1977). Histologic structural modifications of aorta are dictated by the functions it performs, thus elastin/collagen ratio is higher in AA than DA (Hager et al.). Discrepancy of age-related changes between AA and DA was attributed to their functional and histological differences during aging (Hager et al.; Arnonberg et al.; Hannawa et al.). In cardiac patients, diameters of AA and DA found to increase with aging and values of AA were larger than DA.

Previous reports (Cuspidi et al.; Cipolli et al., 2009), noted that hypertension increased the size of abdominal aorta in men but not in women, while our results showed that hypertension significantly increased the TD and CSA of AA and DA in men and women (Table IV). The current study showed that hypertension significantly increased the TD and CSA of PT in men only (Table IV). The present report suggests when PT enlargement clustered with unfavorable cardiac structural changes may have worse prognostic implication on men than on women. This hypothetical sexrelated prognostic value of PT parameters, however, needs to be investigated properly in future prospective designed studies.

Smoking was found to be one of the cardiovascular risk factors associated with larger diameters of DA (Mohiaddin et al., 2011) and could play a role in dilatation of abdominal aorta (Cuspidi et al.). Recently, D'Alessandro et al. (2012) confirmed that nicotine causes vasoconstriction of pulmonary vascular tissue via pathophysiological narrowing mechanism. Another recent study in 2010 confirmed that tobacco smoking involved with the impairment of vasorelaxation of pulmonary vessels (Henno et al., 2011). Evidently, the TD and CSA of the PT in the present study showed significant decreases only in men, since $55 \%$ of them were smokers (Table IV). However, this does not rule out effect of smoking on women since only $13.7 \%$ of them were smokers, which needs further investigation.

Previous reports concluded that despite the fact that diabetes is one of the occlusive vascular risk factors, it does not associate alone with widening of aortic diameter (Dua et al., 2010; Laughlin et al., 2011; Miyama et al., 2010). In addition, diabetic patients found to have smaller aortic root parameters than in non-diabetics (Chen et al., 2009). In contrast, parameters of AA, DA and PT in the present study were larger in diabetics than in non-diabetics of both sexs (Table IV). Table IV showed that TPT and APT increased significantly in diabetic men, may be attributed to testosterone lowering resistance on vasodilatation of PT in men (Rowell et al.). The current study noted that diabetes was a risk factor on parameters of DA and associated with significant increase of TDA and ADA in diabetic women only (Table IV). This could be related to the inhibition effect of estrogen on elastin degradation within aortic wall (Shearman et al.), as well as, the wall of the DA in women contains lesser amount of elastin fibers (Hannawa et al.). Previous reports suggested that etiology of aneurysms in the AA differs than in DA and the pathogenesis of aneurysms in the DA may resemble that of abdominal aorta than AA (Webb \& Higgins). Furthermore, Hannawa et al. and Sato et al. correlated high frequency of aortic aneurysm in postmenopausal women to estrogen deficiency and defined estrogen as the major factor of increasing expandability of aorta. These findings support our result in that part.

In conclusion, transverse diameters and crosssectional areas of the AA, DA and PT correlated well with sex, age, hypertension, smoking and diabetes. In addition, their ratio could be a reliable factor suitable to evaluate aortic and pulmonary diseases. Familiarity of CTA parametric alterations of the AA, DA, and PT by sex, age, hypertension, smoking and diabetes may assist in assessment, suitable approach for medical or surgical intervention and follow-up.

\section{ACKNOWLEDGEMENTS}

The authors express their sincere appreciation to Mr. Wesam Abu AL-Shaikh, CT senior radiographer, Jordan University Hospital, for his technical artistic work.

SHATARAT, A. S.; AL-HADIDI, M. T.; BADRAN, D. H.; BUSTAMI, F. F.; AL-HADIDY, A. M.; TARAWNEH, E. S.; OBEIDAT, N. M. \& ABD EL MALEK, S. W. Parámetros específicos de la parte ascendente de la aorta, parte descendente de la aorta y tronco pulmonar analizados mediante angiografía por tomografía computarizada relacionados con el sexo, impacto de la edad, hipertensión, tabaquismo y diabetes. Int. J. Morphol., 33(4):1411$1418,2015$.

RESUMEN: El objetivo fue determinar si el sexo, edad, hipertensión, tabaquismo y la diabetes alteran el diámetro transversal (DT) y área transversal (AT) de la parte ascendente de la aorta (AA), parte descendente de la aorta (AD) y tronco pulmonar (TP), medidos por angiografía por tomografía computadorizada (ATC). Exámenes de ATC de 100 pacientes de 49,5 $\pm 16,9$ años (rango 16-78 años) fue- 
SHATARAT, A. S.; AL-HADIDI, M. T.; BADRAN, D. H.; BUSTAMI, F. F.; AL-HADIDY, A. M.; TARAWNEH, E. S.; OBEIDAT, N. M. \& ABD EL MALEK, S. W. Sex-Specific parameters of ascending aorta, descending aorta and pulmonary trunk by computed tomographic angiography with impact of age, hypertension, smoking and diabetes. Int. J. Morphol., 33(4):1411-1418, 2015.

ron seleccionados entre enero del año 2009 a mayo del año 2011 por el Departamento de Radiología, Hospital de la Universidad de Jordania, Facultad de Medicina de la Universidad de Jordania, Amman, Jordania para una evaluación avanzada del DT y AT de la AA, AD y TP. Las mediciones se realizaron en el plano axial en el margen superior de las seis vértebras torácicas. Los pacientes fueron divididos en tres grupos según edad. Se determinó la existencia de significancia estadística de los diferentes parámetros entre los grupos etarios. La evaluación de las razones también fueron consideradas. Se encontró que los parámetros de las tres arterias fueron significativamente mayores en los hombres que en las mujeres $(\mathrm{p}=<0,05)$ y que aumentaron con la edad. La hipertensión aumentó los diámetros de la AA y AD en ambos sexos $(p=0,001)$ y del TP en los hombres $(p=0,01)$. En fumadores disminuyeron significativamente los parámetros del TP en los hombres $(\mathrm{p}=0,01)$. La diabetes aumentó los parámetros de las tres arterias en ambos sexos. Ademas, aumentaron significativamente los parámetros del TP en los hombres $(\mathrm{p}=<0,05)$ y los parámetros de la $\mathrm{AD}$ en las mujeres $(\mathrm{p}=<0,05)$. Se concluye que los parámetros estudiados eran mayores en los hombres y aumentaron con la edad de nuestros pacientes. Diferencias distintivas en las mediciones aparecieron en hipertensos, fumadores y pacientes diabéticos.

PALABRAS CLAVE: Aorta ascendente; Aorta descendente; Tronco pulmonar; Angiografía por tomografía computadorizada.

\section{REFERENCES}

Aronberg, D. J.; Glazer, H. S.; Madsen, K. \& Sagel, S. S. Normal thoracic aortic diameters by computed tomography. J. Comput. Assist. Tomogr., 8(2):247-50, 1984.

Chan, A. L.; Juarez, M. M.; Shelton, D. K.; MacDonald, T.; Li, C. S.; Lin, T. C. \& Albertson, T. E. Novel computed tomographic chest metrics to detect pulmonary hypertension. BMC Med. Imaging, 11:7, 2011.

Chen, X. F.; Wang, J. A.; Lin, X. F.; Tang, L. J.; Yu, W. F.; Chen, H.; Xie, X. J.; Jiang, J. J. \& Peng, X. H. Diabetes mellitus: is it protective against aortic root dilatation? Cardiology, 112(2):138-43, 2009.

Cipolli, J. A.; Souza, F. A.; Ferreira-Sae, M. C.; Pio-Magalhães, J. A.; Figueiredo, E. S.; Vidotti, V. G.; Matos-Souza, J. R.; Franchini, K. G. \& Nadruz, W. Jr. Sex-specific hemodynamic and non-hemodynamic determinants of aortic root size in hypertensive subjects with left ventricular hypertrophy. Hypertens. Res., 32(11):956-61, 2009.

Cuspidi, C.; Meani, S.; Negri, F.; Sala, C. \& Mancia, G. Left ventricular hypertrophy and abdominal aorta size in essential hypertension. J. Hypertens., 29(6):1213-9, 2011.

D'Alessandro, A.; Boeckelmann, I.; Hammwhöner, M. \& Goette, A. Nicotine, cigarette smoking and cardiac arrhythmia: an overview. Eur. J. Prev. Cardiol., 19(3):297-305, 2012.
Devaraj, A. \& Hansell, D. M. Computed tomography signs of pulmonary hypertension: old and new observations. Clin. Radiol., 64(8):751-60, 2006.

Dua, M. M.; Miyama, N.; Azuma, J.; Schultz, G. M.; Sho, M.; Morser, J. \& Dalman, R. L. Hyperglycemia modulates plasminogen activator inhibitor-1 expression and aortic diameter in experimental aortic aneurysm disease. Surgery, 148(2):429-35, 2010.

Edwards, P. D.; Bull, R. K. \& Coulden, R. CT measurement of main pulmonary artery diameter. Br. J. Radiol., 71(850):101820, 1998.

Hager, A.; Kaemmerer, H.; Rapp-Bernhardt, U.; Blücher, S.; Rapp, K.; Bernhardt, T. M.; Galanski, M. \& Hess, J. Diameters of the thoracic aorta throughout life as measured with helical computed tomography. J Thorac. Cardiovasc. Surg., 123(6):1060-6, 2002.

Hannawa, K. K.; Eliason, J. L. \& Upchurch, Jr. G. R. Gender differences in abdominal aortic aneurysms. Vascular, 17(Suppl. 1):S30-9, 2009.

Henno, P.; Boitiaux, J. F.; Douvry, B.; Cazes, A.; Lévy, M.; Devillier, P.; Delclaux, C. \& Israël-Biet, D. Tobaccoassociated pulmonary vascular dysfunction in smokers: role of the ET-1 pathway. Am. J. Physiol. Lung Cell. Mol. Physiol., 300(6):L831-9, 2011.

Johnson, D.; Shah, P.; Collins, P. \& Wigley, C. Heart and great vessels. In: Standring, S. (Ed.). Gray's Anatomy: the anatomical basis of clinical practice. 39th ed. Edinburgh, Churchill Livingstone/Elsevier, 2008. pp.1020-5.

Kaplan, S.; Aranow, W. S.; Lai, H.; DeLuca, A. J.; Weiss, M. B.; Dilmanian, H.; Spielvogel, D.; Lansman, S. L. \& Belkin, R. N. Prevalence of an increased ascending and descending thoracic aorta diameter diagnosed by multislice cardiac computed tomography in men versus women and in persons aged 23 to 50 years, 51 to 65 years, 66 to 80 years, and 81 to 88 years. Am. J. Cardiol., 100(10):1598-9, 2007.

Karazincir, S.; Balci, A.; Seyfeli, E.; Akoglu, S.; Babayigit, C.; Akgül, F.; Yalcin, F. \& Egilmez, E. CT assessment of main pulmonary artery diameter. Diag. Interv. Radiol., 14(2):724, 2008.

Laughlin, G. A.; Allison, M. A.; Jensky, N. E.; Aboyans, V.; Wong, N. D.; Detrano, R. \& Criqui, M. H. Abdominal aortic diameter and vascular atherosclerosis: the Multi-Ethnic Study of Atherosclerosis. Eur. J. Vasc. Endovasc. Surg., 41(4):481-7, 2011.

Lin, F. Y.; Devereux, R. B.; Roman, M. J.; Meng, J.; Jow, V. M.; Jacobs, A.; Weinsaft, J. W.; Shaw, L. J.; Berman, D. S.; Gilmore, A.; Callister, T. Q. \& Min, J. K. Assessment of the thoracic aorta by multidetector computed tomography: ageand sex-specific reference values in adults without evident 
SHATARAT, A. S.; AL-HADIDI, M. T.; BADRAN, D. H.; BUSTAMI, F. F.; AL-HADIDY, A. M.; TARAWNEH, E. S.; OBEIDAT, N. M. \& ABD EL MALEK, S. W. Sex-Specific parameters of ascending aorta, descending aorta and pulmonary trunk by computed tomographic angiography with impact of age, hypertension, smoking and diabetes. Int. J. Morphol., 33(4):1411-1418, 2015.

cardiovascular disease. J. Cardiovasc. Comput. Tomogr., 2(5):298-308, 2008.

Mao, S. S.; Ahmadi, N.; Shah, B.; Beckmann, D.; Chen, A.; Ngo, L.; Flores, F. R.; Gao, Y. L. \& Budoff, M. J. Normal thoracic aorta diameter on cardiac computed tomography in healthy asymptomatic adults: impact of age and sex. Acad. Radiol., 15(7):827-34, 2008.

Miyama, N.; Dua, M. M.; Yeung, J. J.; Schultz, G. M.; Asagami, T.; Sho, E.; Sho, M. \& Dalman, R. L. Hyperglycemia limits experimental aortic aneurysm progression. J. Vasc. Surg., 52(4):975-83, 2010.

Mohiaddin, R. H.; Schoser, K.; Amanuma, M.; Burman, E. D. \& Longmore, D. B. MR imaging of age-related dimensional changes of thoracic aorta. J. Comput. Assist. Tomogr., 14(5):748-52, 1990.

Nevsky, G.; Jacobs, J. E.; Lim, R. P.; Donnino, R.; Bab, J. S. \& Srichai, M. B. Sex-specific normalized reference values of heart and great vessel dimensions in cardiac CT angiography. AJR Am. J. Roentgenol., 196(4):788-94, 2011.

Rowell, K. O.; Hall, J.; Pugh, P. J.; Jones, T. H.; Channer, K. S. \& Jones, R. D. Testosterone acts as an efficacious vasodilator in isolated human pulmonary arteries and veins: evidence for a biphasic effect at physiological and supraphysiological concentrations. J. Endocrinol. Invest., 32(9):718-23, 2009.

Rubin, L. J. Pulmonary arterial hypertension. Proc. Am. Thorac. Soc., 3(1):111-5, 2006.

Sato, A.; Yagihara, N.; Kodama, M.; Mitsuma, W.; Tachikawa, H.; Ito, M.; Hanawa, H. \& Aizawa, Y. Takotsubo cardiomyopathy after delivery in an oestrogen-deficient patient. Int. J. Cardiol., 149(2):e78-9, 2009.

Schlatmann, T. J. \& Becker, A. E. Histologic changes in the normal aging aorta: implications for dissecting aortic aneurysm. Am. J. Cardiol., 39(1):13-20, 1977.

Shearman, A. M.; Cupples, L. A.; Demissie, S.; Peter, I.; Schmid, C. H.; Karas, R. H.; Mendelsohn, M. E.; Housman, D. E. \& Levy, D. Association between estrogen receptor alpha gene variation and cardiovascular disease. JAMA, 290(17):226370, 2003.

Towfiq, B. A.; Weir, J. \& Rawles, J. M. Effect of age and blood pressure on aortic size and stroke distance. Br. Heart J., 55(6):560-8, 1986.

Webb, W. R. \& Higgins, C. B. Thoracic Imaging: Pulmonary and Cardiovascular Radiology. $2^{\text {nd }}$ ed. Philadelphia, Lippincott Williams and Wilkins, 2004.
Wolak, A.; Gransar, H.; Thomson, L. E.; Friedman, J. D.; Hachamovitch, R.; Gutstein, A.; Shaw, L. J.; Polk, D.; Wong, N. D.; Saouaf, R.; Hayes, S. W.; Rozanski, A.; Slomka, P. J.; Germano, G. \& Berman, D. S. Aortic size assessment by noncontrast cardiac computed tomography: normal limits by age, sex, and body surface area. JACC Cardiovasc. Imaging, 1(2):200-9, 2008.

\author{
Correspondence to: \\ Dr. Maher T. AL- Hadidi \\ Associate Professor \\ Department of Anatomy and Histology \\ Faculty of Medicine \\ University of Jordan \\ P O Box: 13046 \\ Amman 11942 \\ JORDAN
}

Email: mthadidi@ ju.edu.jo

mthadidi@gmail.com

Received: 17-06-2015

Accepted: 03-09-2015 